\title{
MANAJEMEN BERBASIS SEKOLAH: ALTERNATIF PENINGKATAN MUTU PENDIDIKAN MADRASAH
}

\author{
Ahmad Zaini Aziz \\ Program Magister Pendidikan Islam, Fakultas Ilmu Tarbiyah \\ dan Keguruan UIN Sunan Kalijaga, Yogyakarta \\ Email: ahmadzainiaziz@gmail.com \\ DOI: http://dx.doi.org/10.20885/tarbawi.vol8.iss1.art5
}

\section{Abstract}

This paper is intended to uncover the core issues that exist in madrasah as a root barrier to the improvement of its quality. The results show that madrasah confronts a dilemma as an educational institution. As an educational institution, madrasah should be given broad discretion in its management, especially in the era of regional autonomy. In today's era of autonomy, one of the concepts that can be applied to improve the quality of education is the School-Based Management (SBM). The paper argues that although madrasah is under the auspice of the Department of Religion, the concept of School-Based Management (MBS) can be adopted by madrasah on the basis of its suitability as strategies in coping with madrasah's problems. The implementation of Madrasah-Based Management is intended to improve the quality of madrasah as an Islamic institution.

Keywords: management, quality and madrasah

\section{Abstrak}

Tulisan ini dimaksudkan untuk mengungkap persoalan inti yang ada di Madrasah sebagai akar penghambat dalam peningkatan mutu madrasah. Hasil kajian menunjukkan bahwa Madrasah dihadapakan pada posisi yang dilematis sebagai lembaga pendidikan. Sebagai lembaga pendidikan semestinya Madarasah diberikan kewenangan yang luas dalam pengelolaan madrasah, terlebih saat ini adalah era otonomi daerah. Pada era otonomi saat ini salah satu konsep yang dapat diterapkan untuk meningkatkan mutu pendidikan adalah dengan Manajemen berbasis sekolah. MBS merupakan strategi untuk mewujudkan sekolah menjadi lebih bermutu 
dengan memberikan wewenang yang luas kepada Madrasah. Walaupun Madrasah berada di bawah naungan Departemen Agama namun konsep MBS tetap dapat diimplementasikan berdasaran atas kesesuaian MBS sebagai strategi mengatasi masalah Madrasah. Pengimplementasian Manajemen Berbasis Madrasah dimaksudkan untuk meningkatkan kualitas madrasah sebagai lembaga pendidikan Islam.

Kata Kunci: manajemen, mutu, madrasah

\section{Pendahuluan}

Salah satu permasalahan pendidikan yang dihadapi oleh bangsa Indonesia saat ini adalah rendahnya mutu di berbagai lembaga pendidikan, khusunya di lembaga pendidikan Islam seperti madrasah. Rendahnya kualitas pendidikan Islam tersebut meniscayakan adanya berbagai upaya dalam meningkatkan mutu pendidikan oleh semua pihak. Sebenarnya, madrasah sebagai lembaga pendidikan Islam telah melakukan berbagai upaya dalam meningkatkan mutu pendidikan. Beberapa upaya peningkatan mutu seperti pengembangan kurikulum, peningkatan kompetensi tenaga pendidik melalui pelatihan, peningkatan manajemen pendidikan, dan pengadaan serta perbaikan sarana prasarana pendidikan merupakan langkah maju untuk menjadikan lembaga pendidikan Islam lebih berkualitas. Upayaupaya tersebut dilandasi suatu kesadaran bahwa betapa pentingnya peranan pendidikan dalam pengembangan sumber daya manusia dan pengembangan watak bangsa (Mulyasa, 2005: 31). Namun demikian, berbagai indikator mutu pendidikan Islam belum menunjukan peningkatan yang berarti.

Beberapa dugaan muncul perihal sebab musabab peningkatan mutu pendidikan Islam yang bergerak kurang signifikan. Menurut hemat penulis beberapa kemungkinan yang menjadi alasan rendahnya tingkat mutu pendidikan Islam di Indonesia adalah pertama, adanya penyelenggaraan pendidikan yang kurang memperhatikan pada tahap proses. Padahal, proses pendidikan sangat menentukan kualitas output/ lulusan yang ada.

Kedua, penyelenggaran pendidikan Islam dilakukan secara birokratik-sentralistik sehingga penyelenggara pendidikan sangat 
tergantung pada keputusan birokrasi dan kadang-kadang kebijakan yang dikeluarkan tidak sesuai dengan kondisi yang ada. Madrasah lebih merupakan subordinasi birokrasi diatasnya sehingga mereka kehilangan kemandirian, keluwesan, motivasi, kreativitas, inisiatif untuk mengembangkan dan memajukan lembaganya termasuk peningkatan mutu pendidikan sebagai salah satu tujuan pendidikan nasional.

Ketiga, adanya hubungan yang kurang harmonis antara lembaga pendidikan Islam khususnya madrasah dengan masyarakat. Selama ini peran serta warga sekolah khususnya guru dan peran serta masyarakat khususnya orang tua siswa dalam penyelenggaraan pendidikan sangat minim.Partisipasi guru dalam pengambilan keputusan sering diabaikan, partisipasi masyarakat pada umumnya sebatas pada dukungan dana. Sehingga seolah tidak ada hubungan timbal balik antara lembaga pendidikan dengan masyarakat.

Permasalahan di atas semestinya dapat teratasi seiring dengan lahirnya Undang-Undang No 22 tahun 1999 tentang Otonomi Daerah dan Undang-Undang No 25 tentang Perimbangan Keuangan Pusat dan Daerah. Undang-undang tersebut membawa konsekuensi terhadap bidang-bidang kewenangan daerah sehingga lebih otonom, termasuk pada bidang pendidikan (Mulyasa, 2014: 4).

Undang-undang tersebut memang memberikan langkah solusi dengan berbagai persolan yang ada di madrasah. Keambiguan posisi madrasah sebagai lembaga pendidikan menjadikan madrasah tetap berada di bawah Departemen Agama dengan sistem sentralisasi yang seolah menafikan Undang-Undang Otonomi Daerah. Padalah, secara legal madrasah dan lembaga pendidikan yang bercirikan Islam lainnya sudah terintegrasi dalam sistem pendidikan nasional sejak diberlakukannya Undang-Undang Nomor 2 Tahun 1989 tentang Sistem Pendidikan Nasional.

Era otonomi dengan asas desentralisasi ini menuntut partisipasi dan pemberdayaan seluruh komponen pendidikan dan penerapan konsep pendidikan sebagai suatu sistem. Peningkatan mutu pendidikan dalam kerangka otonomi daerah merubah arah dan paradigma penyelenggaraan yang dulunya dengan pola sentralisasi ke 
arah pendidikan yang desentralisasi (Tilaar, 2004: 31). Adapun model penyelenggaraan pendidikan untuk mencapai mutu pendidikan yang sesuai dengan paradigma desentralisasi dewasa ini adalah dengan konsep School-Based Management atau Manajemen Berbasis Sekolah (MBS). Manajemen Berbasis Sekolah (MBS) hadir sebagai reorientasi mutu dalam penyelenggaraan pendidikan.

Tulisan ini berusaha mengakaji konsep Manajemen Berbasis Sekolah dalam meningkatkan mutu pendidikan di madrasah. Menarik untuk dibahas mengingat madrasah merupakan lembaga pendidikan yang berada di bawah naungan Departemen Agama dengan sistem sentralisasi. Oleh karenanya, tulisan ini juga berusaha mengkaji kemungkinan madrasah dapat mengimplementasikan Manajemen Berbasis Sekolah sebagai sebuah alternatif peningkatan mutu pendidikan madrasah.

\section{Otonomi Daerah}

Pemahaman otonomi daerah di Indonesia dilandaskan pada kebijakan publik tentang otonomi daerah yaitu Undang-Undang No 23 tahun 2004 tentang Pemerintahan Daerah yang menyebutkan bahwa otonomi daerah adalah hak, wewenang, dan kewajiban daerah otonom untuk mengatur dan mengurus sendiri urusan pemerintahan dan keperntingan masyarakat setempat sesuai dengan peraturan perundang-undangan. Daerah otonom adalah kesatuan masyarakat hukum yang memunyai batas-batas wilayah yang berwenang mengatur dan mengurus urusan pemerintahan dan kepentingan masyarakat setempat menurut prakarsa sendiri berdasarkan aspirasi masyarakat. Otonomi merupakan produk atau desentralisasi. Untuk itu dalam memahami otonomi daerah dapat dilakukan dengan melakukan pemahaman terhadap desentralisasi (Nugroho, 2008: 23).

Secara umum desentralisasi dapat dipahami sebagai pendelegasian sejumlah wewenang kepada otoritas yang lebih rendah. Tujuannya adalah agar penyelenggaraan otonomi daerah dapat memberikan manfaat yang optimal bagi rakyat daerah, khususnya dalam arti terciptanya kesejahteraan yang merata di daerah (Nugroho, 2008: 27). Menurut Ara Hidayat dan Imam Machali, desentralisasi adalah penyerahan kewenangan dari pemerintah pusat kepada pemerintah daerah untuk mengurusi urusan rumah tangganya sendiri berdasarkan 
prakarsa dan aspirasi dari rakyatnya dalam kerangka NKRI. Dengan adanya desentralisasi maka muncullah otonomi bagi suatu pemerintah daerah (Hidayat dan Machali, 2012: 50).

Munurut Dennis A. Rondinelli, sebagaimana dikutip oleh Hidayat (2012), desentralisasi mempunyai empat bentuk yaitu dekonsentrasi, delegasi, devolusi dan privatisasi. Penjelasan masih-masing istilah sebagai berikut. Dekonsentrasi adalah pembagian sebagian kewenangan atau tanggungjawab administratif ke tingkat yang lebih rendah di bawah departemen dan perwakilan pemerintah pusat. Delegasi adalah pelimpahan pengambilan keputusan dan kewenangan manajerial untuk melakukan tugas-tugas khusus kepada suatu organisasi yang tidak secara langsung berada di bawah pengawasan pemerintah pusat. Devolusi merupakan transfer kewenangan untuk pengambilan keputusan, keuangan dan manajemen kepada unit otonomi daerah. Privatisasi adalah tindakan pemberian kewenangan dari pemerintah kepada badan-badan sukarela, swasta, dan swadaya masyarakat. Keempat bentuk tersebut menjadi model desentralisasi di Indonesia sesuai dengan Undang-Undang No 32 tahun 2004 tentang Pemerintah Daerah.

Selain itu, pemahaman tentang desentralisasi perlu juga dipahami dalam berbagai kontek keotonomian. Otonomi luas adalah kewenangan dan keleluasaan pemerintah dalam menyelenggarakan seluruh bidang kehidupan kecuali politik luar negeri, pertahanan keamanan, peradilan, moneter dan fiskal, agama serta bidang yang ditetapkan oleh peraturan pemerintah. Otonomi luas secara menyeluruh penyelenggaraan pemerintahan mulai dari perencanaan, pelaksanaan, pengawasan, pengendalian, dan evaluasi. Otonomi nyata adalah keleluasaan daerah melaksanakan kewenangan pemerintahan dalam bidang tertentu yang secara nyata ada dan diperlukan serta tumbuh, hidup, dan berkembang di daerah. Otonomi yang bertanggungjawab merupakan perwujudan dan pertanggungjawaban terhadap permberian hak dan wewenang kepada daerah. Hal ini diwujudkan dalam bentuk tugas dan kewajiban yang harus diemban oleh daerah untuk mencapai tujuan pemberian otonomi (Mulyasa, 2014: 5).

Pelimpahan wewenang kepada daerah atau desentralisasi membahwa konsekuensi terhadap pembiayaan guna mendukung proses desentralisasi sebagaimana termuat dalam pasal 8 Undang-Undang No 22 tahun 1999. Untuk itu, dikeluarkan Undang-Undang No 25 tahun 
1999 tentang Perimbangan Keuangan antara Pemerintah Pusat dan Daerah yang bertujuan memberdayakan dan meningkatkan kemampuan perekonomian daerah, menciptakan sistem pembiayaan daerah yang adil, proposrsional, rasional, transparan, partisipatif, bertanggungjawab, dan pasti, serta mewujudkan sistem perimbangan keuangan antara pusat dan daerah (Mulyasa, 2014: 6).

Berdasarkan penjelasan konsep otonomi tersebut penulis merumusakan bahwa otonomi pada hakikatnya memberikan kewenangan dan keleluasaan kepada daerah untuk mengatur dan mengurus kepentingan masyarakat setempat. Penyelenggaraan otonomi daerah dilaksanakan dengan memberi kewenangan yang luas, nyata, dan bertanggung jawab kepada daerah secara proporsional yang diwujudkan dalam peraturan, pembagian, dan pemanfaatan sumber daya nasional yang berkeadilan serta perimbangan antara keuangan pusat dan daerah.

\section{Desentralisasi Pendidikan}

Dalam manajemen pendidikan dikenal dua mekanisme pengaturan, yaitu sistem sentralisasi dan desentralisasi. Dalam sistem sentralisasi, segala sesuatu yang berkenaan dengan penyelenggaraan pendidikan diatur secara ketat oleh pemerintah pusat. Sementara dalam sistem desentralisasi, wewenang pegaturan tersebut diserahkan kepada pemerintah daerah (Mulyasa, 2014: 22). Konsep desentralisasi ini telah diatur dalam UndangUndang No 22 tahun 1999 tentang Otonomi Daerah.

Pemberlakuan Undang-Undang No. 22 tahun 1999 tentang Otonomi Daerah mengisyaratkan mengenai kemungkinan-kemungkinan pengembangan suatu wilayah dalam suasana yang lebih kondusif dan dalam wawasan yang lebih demokratis. Termasuk berbagai kemungkinan pengelolaan dan pengembangan dalam bidang pendidikan. Pemberlakuan undang-undang tersebut menuntut adanya perubahan pengelolaan pendidikan dari yang bersifat sentralistik kepada yang lebih bersifat desentralistik (Chan dan Sam, 2007: 2). Desentralisasi dalam pendidikan dimaksudkan untuk meningkatkan mutu pendidikan khususnya dari segi manajeman dan pengelolaan.

Ketentuan otonomi daerah yang dilandasi oleh Undang-Undang Nomor 22 dan Nomor 25 tahun 1999 sebagaimana diuraikan di atas secara otomatis telah membawa perubahan dalam bidang pendidikan. Pada awalnya manajemen pendidikan merupakan wewenang pusat, 
namun dengan berlakunya undang-undang tersebut maka kewenangan dialihkan ke daerah dalam hal ini kota atau kabupaten. Berkenaan dengan hal tersebut maka muncul berbagai pengertian tentang desentralisasi pendidikan.

Menurut Fasli Djalal, seperti dikutip Riant Nugroho (2008), terdapat relasi antara desentralisasi dengan manajemen pendidikan. Desentralisasi pendidikan adalah sistem manajemen untuk mewujudkan pembangunan pendidikan yang menekankan kepada kebhinekaan. Desentralisasi pendidikan diartikan sebagai pelimpahan wewenang yang lebih luas (Nugroho, 2008: 28).

Pengertian tersebut di atas mengandung prinsip subsidiaritas yaitu segala sesuatu yang telah dilakukan lembaga di bawah maka tidak perlu dilakukan lembaga di atasnya. Perlu dipahami bahwa prinsip ini bukan berarti pemerintah pusat lepas tangan dari pelaksanaan pendidikan. Desentralisasi tidak hanya mendorong pemerintah nasional membangun manajemen pendidikan yang terdesentralisasi, melainkan juga menjadi pendorong bagi daerah untuk mengembangkan manajemen pendidikan yang bermutu.

Adapun yang dimaksud dengan desentralisasi manajemen pendidikan adalah pelimpahan wewenang dari pemerintah pusat kepada daerah untuk membuat keputusan manajemen dan menyusun perencanaan sendiri dalam mengatasi masalah pendidikan dengan mengacu kepada sistem pendidikan nasional. Desentralisasi pendidikan dapat diterapkan dalam beberapa tingkat dan struktur organisasi penyelenggaraan pendidikan, mulai dari tingkat pusat sampai tingkat satuan pendidikan. Sedangkan tujuan dari desentralisasi manajemen pendidikan adalah untuk meningkatkan efektifitas dan efesiensi manajemen dan kepuasan kerja pegawai melalui pemecahan masalah-masalah yang berhubungan langsung dengan daerah lokal. Desentralisasi manajemen pendidikan berusaha mengurangi campur tangan atau intervensi pejabat atau unit pusat terhadap persoalan-persoalan pendidikan yang sepatutnya dapat diputuskan dan dilaksanakan oleh unit di tataran bawah, pemerintah daerah atau masyarakat (Hidayat dan Machali, 2012: 52).

Berdasarkan paparan di atas, inti dari diberlakukannya desentralisasi dalam pendidikan adalah untuk meningkatkan mutu pendidikan di setiap lembaga pendidikan. Berkaitan dengan peningkatan mutu pendidikan 
dalam era otonomi daerah maka beberapa hal yang perlu direkontruksi dalam pendidikan nasional adalah: pertama, upaya peningkatan mutu pendidikan dilakukan dengan menetapkan tujuan dan standar kompetensi pendidikan, yaitu melalui konsensus nasional antara pemerintah dengan seluruh lapisan masyarakat. Standar kompetensi yang mungkin akan berbeda antar sekolah atau antar daerah akan menghasilkan standar kompetensi nasional dalam tingkatan standar minimal, normal, dan unggulan. Kedua, peningkatan efesiensi pengelolaan pendidikan mengarah pada pengelolaan pendidikan berbasis sekolah, dengan memberi kepercayaan yang lebih luas kepada sekolah untuk mengoptimalkan sumber daya yang tersedia bagi tercapainya tujuan pendidikan yang diharapkan. Ketiga, peningkatan relevansi pendidikan mengarah pada pengelolaan pendidikan berbasis masyarakat. Penigkatan peran serta orang tua dan masyarakat pada level kebijakan (pengambil keputusan) dan level operasional melalui komite sekolah. Peran komite meliputi perencanaan, implementasi, monitoring, serta evaluasi program kerja sekolah.Keempat pemerataan pelayanan pendidikan mengarah pada pendidikan yang berkeadilan. Hal ini berkenaan dengan penerapan formula pembiayaan pendidikan yang adil dan transparan (Mulyasa, 2014: 7).

\section{Manajemen Sekolah}

Manajemen atau pengelolaan merupakan komponen integral yang tidak dapat dipisahkan dari proses pendidikan. Alasannya tanpa manajemen tidak mungkin tujuan pendidikan dapat diwujudkan secara optimal, efektif, dan efesien. Berdasarkan fungsi dari manajemen tersebut penulis perlu kiranya menjelaskan beberapa pengertian tentang manajemen sekolah atau manajemen pendidikan.

Manajemen pendidikan adalah gabungan dari dua kata yang memunyai satu makna, yaitu manajemen dan pendidikan. Secara sederhana, manajemen pendidikan dapat diartikan sebagai manajemen yang dipraktikan dalam dunia pendidikan dengan spesifikasi dan ciri khas yang ada dalam pendidikan. Manajemen pendidikan pada dasarnya adalah sebuah alat yang diperlukan dalam usaha mencapai tujuan pendidikan. Unsur manajemen dalam pendidikan merupakan penerapan prinsip-prinsip manajemen dalam bisang pendidikan. Manajemen pendidikan merupakan rangkaian proses yang terdiri dari perencanaan, pengorganisasian, penggerakan, dan pengawasan 
yang dikaitkan dengan dunia pendidikan (Kurniadin dan Machali, 2012: 117).

Husaini Usman mendefiniskan manajemen pendidikan sebagai seni dan ilmu mengelola sumber daya pendidikan untuk mewujudkan proses dan hasil belajar peserta didik secara aktif, kreatif, inovatif, dan menyenangkan dalam mengembangkan potensi dirinya. Manajemen adalah seni dan ilmu mengelola sumber daya pendidikan mencapai tujuan pendidikan secara aktif dan efesien. Manajemen pendidikan adalah proses perencanaan, pengorganisasian, pengarahan, dan pengendalian sumber daya pendidikan untuk mencapai tujuan pendidikan (Usman, 2013: 14).

Dalam memahami manajemen pendidikan perlu kiranya memahami fungsi-fungsi pokok manajemen sebagaimana yang telah disebutkan dalam definisi di atas. Beberapa fungsi tersebut dapat dideskripsikan sebagai berikut, perencanaan adalah proses menetapkan tujuan melalui cara atau metode yang tepat dan sistematis untuk mencapai tujuan atau seperangkat tujuan. Melalui perencanaan ini sebuah lembaga pendidikan dapat menyusun prosedur atau metode terbaik dalam menjalankan kegiatan. Pengorganisasian adalah proses membentuk kerja sama anatara dua individu atau lebih dalam sebuah struktur tertentu untuk mencapai tujuan. Tujuan yang berbeda memerlukan struktur yang berbeda, sehingga diperlukan upaya penyusunan stuktur organisasi melalui suatu desain pengorganisasian. Pengarahan adalah proses mengarahkan dan memengaruhi anggota organisasi secara individu maupun keseluruhan dalam malaksanakan berbagai kegiatan untuk mencapau tujuan. Pengendalian adalah proses menjamin atau memastikan bahwa kegiatan yang dilaksanakan untuk mencapau tujuan harus sesuai dengan rencana yang dibuat. Tiga unsur penting pengendalian dalam pendidikan adalah standar kinerja, pengukuran kinerja yang telah dilaksanakan, dan perbandingan antara kinerja yang dilaksanakan dengan standar kerja. Apabila ditemukan penyimpangan dalam melaksanakan kegiatan maka pemimpin dapat melakukan perbaikan guna menghilangkan atau mengurangi penyimpangan tersebut (Nafis, 2011: 28-30).

Berdasarkan paparan mengenai manajemen pendidikan pada intinya manajemen adalah sebuah keharusan yang ada dalam lembaga pendidikan.Jika manajemen dalam sebuah lembaga pendidikan baik maka dapat dipastikan lembaga pendidikan tersebut berkualitas dan bermutu. Upaya peningkatan mutu dalam menejemen lembaga pendidikan 
ini memunculkan sebuah konsep yang disebut dengan manajemen berbasis sekolah yang memberikan kewenangan penuh kepada sekolah dan guru dalam mengatur pendidikan dan pengajaran, merencanakan, mengorganisasi, mengawasi, mengendalikan serta mengembankan seluruh sumber daya pendiidkan.

\section{Konsep Manajemen Berbasis Sekolah}

Istilah manajemen berbasis sekolah merupakan terjemahan dari School-Based Management. Istilah ini pertama kali muncul di Amerika Serikat ketika masyarakat mulai mempertanyakan relevansi pendidikan dengan tuntutan dan perkembangan masyarakat setempat. MBS merupakan paradigma baru pendidikan yang memberikan otonomi luas pada tingkat sekolah (pelibatan masyarakat) dalam kerangka kebijakan pendidikan nasional. Otonomi diberikan agar sekolah leluasa mengelola sumber daya dan sumber dana dengan mengalokasikannya sesuai dengan prioritas kebutuhan.

Otonomisasi penyelenggaraan pendidikan melahirkan sebuah perspektif baru dalam pengelolaan pendidikan yang disebut dengan Manajemen Berbasis Sekolah. Otonomi sekolah atau desentralisasi pengelolaan sekolah berarti pengelolaan pendidikan berdasarkan kebutuhan sekolah atau masyarakat. Secara konseptual MBS dapat diartikan sebagai sebuah model pengelolaan yang memberikan kewenangan lebih besar keapada sekolah sehingga sekolah dan masyarakat terlibat aktif dalam penyelenggaraan pendidikan.

Pelibatan masyarakat dimaksudkan agar masyarakat selaku stakeholder sekolah lebih memahami, membantu dan mengontrol pengelolaan pendidikan. Dalam pada itu, kebijakan nasional yang menjadi prioritas pemerintah tetap harus dijalankan oleh sekolah. Pada sistem MBS, sekolah dituntut secara mandiri untuk menggali, mengalokasikan, menentukan prioritas, mengendalikan, dan mempertanggungjawabkan pemberdayaan sumber-sumber baik kepada masyarakat maupun pemerintah (Mulyasa, 2014: 24).

Konsep MBS yang demikian adanya memang berangkat dari tuntutan diterapkannya kebijakan desentralisasi dan otonomi daerah. Undang-Undang Nomor 32 Tahun 2004 tentang Pemerintah Daerah dan Nomor 33 Tahun 2004 tentang Perimbangan Keuangan Pusat dan Daerah (pergantian Undang-Undang Nomor 22 dan Nomor 25 Tahun 
1999) telah membawa perubahan dalam berbagai bidang kehidupan termasuk bidang penyelenggaraan pendidikan. Kewenangan yang diberikan pemerintah pusat kepada pemerintah daerah melahirkan kebijakan desentralisasi dan otonomi, yaitu kewenangan pemerintah daerah untuk mengatur daerahnya sendiri dengan tetap mengedepankan pemerintah pusat sebagai control of governance (Hidayat dan Machali, 2012: 53).

Pada intinya MBS merupakan salah satu wujud dari reformasi pendidikan yang menawarkan kepada sekolah untuk menyediakan pendidikan yang lebih baik dan memadai bagi para peserta didik. Otonomi dalam manajemen merupakan potensi bagi sekolah untuk meningkatkan kinerja para staf dan menawarkan pastisipasi langsung kepada masyarakat terhadap pendidikan. Kewenangan yang bertumpu pada sekolah merupakan inti dari MBS yang dipandang memiliki tingkat efektivitas tinggi serta memberikan beberapa keuntungan berikut:

a. Kebijakan dan kewenangan sekolah membawa pengaruh langsung kepada peserta didik, orang tua, dan guru.

b. Bertujuan bagaimana memanfaatkan sumber daya local.

c. Efektif dalam melakukan pembinaan peserta didik seperti kehadiran, hasil belajar, tingkat pengulangan, tingkat putus sekolah, moral guru, dan iklim sekolah.

d. Adanya perhatian bersama untuk mengambil keputusan, memberdayakan guru, manajemen sekolah, rancang ulang sekolah, dan perubahan perencanaan (Mulyasa, 2014: 25).

Melihat keuntungan dari MBS di atas maka sekolah dan daerah dituntut untuk mampu memberdayakan diri untuk meningkatkan mutu pendidikan. Dalam hal ini sekolah memiliki full authority and responsibility dalam menetapkan program-program pendidikan dan berbagai kebijakan sesuai dengan tujuan pendidikan. Perlu dipahami bahwa semua kebijakan dan program sekolah ditetapkan oleh komite sekolah dan dewan pendidikan yang dibentuk berdasarkan musyawarah dari pejabat daerah, kepala sekolah, tenaga kependidikan, perwakilan orang tua peserta didik, dan tokoh masyarakat.

\section{Prinsip Manajemen Barbasis Sekolah}

Terdapat empat prinsip manajemen berbasis sekolah sebagai bentuk implementasi otonomi daerah bidang pendidikan yang menjadi landasan 
dalam menerjemahkan konsep manajemen peningkatan mutu berbasis sekolah sesuai dengan tujuannya, yaitu otonomi, fleksibilitas, partisipasi, dan inisiatif.

a. Prinsip otonomi

Prinsip otonomi diartikan sebagai kemandirian, yaitu kemandirian dalam mengatur dan mengurus diri sendiri. Kemandirian dalam program dan pendanaan merupakan tolok ukur utama kemandirian sekolah. Kemandirin yang berlangsung secara terus menerus akan menjamin keberlangsungan hidup dan perkembangan sekolah.

b. Prinsip fleksibelitas

Prinsip fleksibelitas dapat diartikan sebagai keluwesan uang diberikan kepada sekolah untuk mengelola, memanfaatkan, dan memberdayakan sumber daya sekolah seoptimal mungkin untuk meningkatkan mutu sekolah. Prinsip ini akan melahirkan sekolah yang lebih lincah dalam bergerak dan tanggap terhadap permasalahan yang harus dihadapi.

c. Prinsip partispasi

Prinsip partisipasi dapat diartikan dengan penciptaan lingkunagn yang terbuka dan demokratik. Warga sekolah (guru, siswa, karyawan) dan masyarakat didorong untuk telibat langsung dalam penyelenggaraan pendidikan, mulai dari pengambilan keputusan, pelaksanaan, dan evaluasi untuk meningkatkan mutu pendidikan. Hal ini dilandasi dengan keyakinan bahwa jika seorang dilibatkan maka yang bersangkutan akan mempunyai "rasa memiliki" terhadap sekolah, sehingga yang bersangkutan juga akan bertanggung jawab dalam penyelenggaraan pendidikan ke arah yang lebih bermutu.

\section{d. Prinsip inisiatif}

Prinsip ini didasari atas konsepsi bahwa manusia bukanlah sumber daya yang statis, melainkan dinamis. Oleh karena itu, potensi sumber daya manusia harus selalu digali, ditemukan, dan dikembangkang untuk menjadi sumber daya yang inisiatif dalam pengelolaan pendidikan (Hidayat dan Machali, 2012: 56). 


\section{Tujuan dan Manfaat Manajemen Berbasis Sekolah}

Penerapan pengelolaan pendidikan dengan model MBS bertujuan untuk meningkatkan efesiensi, mutu, dan pemerataan pendidikan. Peningkatan efesiensi terutama diperoleh dari keleluasaan yang diberikan untuk mengelola sumber daya partisipasi masyarakat dan penyederhanaan birokrasi.

Peningkatan mutu dapat diperoleh antara lain melalui partisipasi orang tua terhadap sekolah, fleksibelitas pengelolaan sekolah dan kelas, peningkatan profesionalisme guru dan kepala sekolah, serta pemberlakukan sistem insentif dan disentif.

Peningkatan pemerataan dapat diperoleh melalui peningkatan partisipasi masyarakat yang memungkinkan pemerintah untuk lebih berkosentrasi pada kelompok tertentu. Hal ini dimungkinan karena pada sebagian masyarakat tumbuh rasa kepemilikan yang tinggi terhadap sekolah (Hidayat dan Machali, 2012: 57).

Penerapan manajemen berbasis sekolah banyak memberikan manfaat. Hal ini dikarenakan MBS memberikan kebebasan dan keleluasaan yang besar pada sekolah, disertai seperangkat tanggungjawab. Dengan adanya otonomi yang memberikan keleluasaan tersebut maka sekolah dapat lebih meningkatkan kesejahteraan guru sehingga dapat lebih berkosentrasi pada tugas. Selain itu, penerapan MBS juga dapat mendorong profesioanlisme guru dan kepala sekolah sebagai pemimpin sekolah, hal ini dikarenakan konsep MBS menghendaki kebebasan kepada guru dan kepala sekolah dalam menyusun kurikulum dan program sekolah. Adanya kesempatan untuk menyusun kurikulum dan program kepada guru dan kepala sekolah tentunya kurikulum yang terbentuk akan sesuai dengan kebutuhan masyarakat (tepat sasaran). Dengan demikian rasa tanggap sekolah kepada kebutuhan masyrakat meningkan dan menjamin layanan pendidikan sesuai dengan tuntutan peserta didik dan masyarakat.

MBS menekanakan keterlibatan maksimal berbagai pihak, seperti pada sekolah-sekolah swasta, sehingga menjamin partisipasi staf, orang tua, peserta didik, dan masyarkat yang lebih luas dalam perumusanperumusan keputusan tentang pendidikan. Kesempatan partisipasi tersebut dapat meningkatkan komitmen mereka terhadap sekolah. 
Selanjutnya, aspek-aspek tersebut pada akhirnya akan mendukung efektivitas dalam pencapaian tujuan sekolah. Adanya kontrol dari masyarkat dan monitoring dari pemerintah, pengelola sekolah menjadi akuntabel, transparan, egaliter, dan demokratis, serta menghapuskan monopoli dalam pengelolaan pendidikan (Mulyasa, 2014: 26).

\section{Karakteristik Manajemen Berbasis Sekolah}

Karakteristik manajemen peningkatan mutu berbasis sekolah dapat diketahui dengan bagaimana sekolah dapat mengoptimalkan kinerjanya. Beberapa kiberja yang dapat menajadi acuan adalah, proses pembelajaran, pengelolaan sumber belajar, profesionalisme tenaga kependidikan, serta sistem administrasi secara keseluruhan.

Karakteristik manajemen peningkatan mutu berbasis sekolah secara inklusif memuat elemen-elemen sekolah efektif yang dikategorikan menjadi input, proses dan output. Karakteristik ini menerapkan pada keseluruhan aspek pendidikan melalui pendekatan sistem. Penguraian ketiganya diawali dengan output dan diakhiri dengan input.

Output sekolah diukur dengan kinerja sekolah, yaitu pencapaian atau prestasi yang dihasilkan oleh proses sekolah. Kinerja sekolah dapat diukur dari efektivitas, kualitas, produktivitas, efisiensi, inovasi, moral kerja. Proses sekolah adalah proses pengambilan keputusan,pengelolaan kelembagaan, pengelolaan program, dan belajar-mengajar. Input sekolah antara lain visi, misi, tujuan, sasaran, struktur organisasi, input manajemen, input sumber daya (Nurkolis, 2003: 111).

Saud, seperti dikutip Mulayasa (2014), menjelaskan bahwa karakteristik dasar MBS adalah pemberian otonomi yang luas kepada sekolah, partisipasi masyarakat dan orang tua peserta didik yang tinggi, kepemimpinan sekolah yang demikratis dan profesional, serta adanya team work yang profesional.

a. Pemberian otonomi luas kepada sekolah

MBS memberikan otonomi yang luas kepada sekolah disertai seperangkat tanggung jawab pengelolaan sumber daya dan pengembangan strategi sesuai dengan kondisi setempat, sekolah dapat lebih memberdayakan tenaga kependidikan agar lebih berkosentrasi pada tugas utamanya. Dalam hal itu, sekolah sebagai lembaga pendidikan diberi kewenangan dan kekuasaan yang luas untuk mengembangkan 
program-program kurikulum dan pembelajaran sesuai dengan kondisi dan kebutuhan peserta didik serta tuntutan masyarakat.

b. Partisipasi masyarakat dan orang tua

Pelaksanaan program-program sekolah didukung oleh partisipasi masyarakat dan orang tua peserta didik yang tinggi. Orang tua peserta didik dan masyarakat tidak hanya mendukung sekolah melalui bantuan keuangan, tetapi melalui komite sekolah dan dewan pendidikan merumuskan serta mengembangkan program-program yang dapat meningkatkan kualitas sekolah. Masyarakat dan orang tua menjalin kerja sama untuk membantu sekolah sebagai narasumber barbagai kegiatan sekolah untuk meningkatkan kualitas pembelajaran.

c. Kepemimpinan yang demokratis dan profesional

Sama halnya dengan partisipasi masyarakat program-program sekolah tidak akan berjalan baik tanpa kepemimpinan sekolah yang demokratis dan profesional. Kepala sekolah dan guru sebagai pelaksana inti program-program sekolah merupakan orang-orang yang memiliki kemampuan dan integritas profesional. Kepala sekolah adalah manajer sekolah yang direkrut komite sekolah untuk mengelola segala kegiatan sekolah berdasarkan kebijakan yang telah ditetapkan. Guru-guru yang direkrut oleh sekolah adalah pendidik profesional dalam bidangnya masing-masing, sehingga baik kepala sekolah maupuan para guru bekerja berdasarkan pola kinerja profesional yang disepakati bersama untuk memberi kemudahan dan mendukung keberhasilan pembelajaran peserta didik. Dalam pengambilan keputusan kepala sekolah mengimplementasikan proses bottom up secara demokratis, sehingga semua pihak memiliki tanggung jawab terhadap keputusan yang diambil berserta pelaksanaannya.

d. Team work yang kompak dan transparan

Adaya tim yang kompak dalam menjalankan program sekolah sangat menentukan tingkat keberhasilan sekolah dalam mencapai tujuan pendidikan. Semua pihak yang terlibat dalam pelaksanaan pengelolaan pendidikan berjalan harmonis dan saling membutuhkan. Dengan demikian keberhasilan MBS merupakan hasil sinergi (sinergistic effect) dari kolaborasi tim yang kompak dan transparan (Mulyasa, 2014: 36-38).

Menurut Levavic dalam Bafadal (2006), terdapat tiga karakteristik kunci MBS, yaitu sebagai berikut: 
a. Kekuasaan dan tanggung jawab dalam pengambilan keputusan yang berhubungan peningkatan mutu pendidikan didesentralisasikan kepada para stakeholder sekolah.

b. Domain manajemen peningkatan mutu pendidikan yang mencakup keseluruhan aspek peningkatan mutu pendidikan, mencakup keuangan, kepegawaian, sarana dan prasarana, penerimaan siswa baru, dan kurikulum.

c. Walaupun keseluruhan domain manajemen peningkatan mutu pendidikan didesentralisasikan ke sekolah-sekolah, namun diperlukan adanya sejumlah regulasi yang mengatur fungsi control pusat terhadap keseluruhan pelaksanaan kewenangan dan tanggungjawab sekolah (Bafadal, 2006: 82).

\section{Faktor-Faktor Penting dalam Manajemen Berbasis Sekolah}

Terdapat beberapa faktoryang perlu diperhatikan dalam peningkatan manajemen mutu berbasis sekolah. Faktor-faktor tersebut berkaitan dengan kewajiban sekolah, kebijakan dan prioritas pemerintah, peranan orang tua dan masyarakat, peranan profesionalisme dan manajerial, serta pengembangan profesi.

a. Kewajiban sekolah

Manajemen berbasis sekolah yang menawarkan keleluasaan pengelolaan sekolah memiliki potensi yang besar dalam menciptakan kepala sekolah, guru, dan pengelola sistem pendidikan profesional. Oleh karena itu, pelaksanaannya perlu disertai seperangkat kewajiban, serta monitoring dan tuntutan pertanggungjawaban yang relatif tinggi untuk menjamin bahwa sekolah selain memiliki otonomi juga memunyai kewajiban melaksanakan kebijakan pemerintah dan memenuhi harapan masyarakat sekolah.

b. Kebijakan dan prioritas pemerintah

Pemerintah sebagai penanggung jawab pendidikan nasional berhak merumuskan kebijakan-kebijakan yang menjadi prioritas nasional terutama yang berkaitan dengan program peningkatan melek huruf dan angka, efesiensi, mutu, dan pemerataan pendidikan. Dalam hal-hal tersebut sekolah tidak diperbolehkan berjalan sendiri dengan mengabaikan kebijakan dan standar yang ditetapkan oleh pemerintah yang dipilih secara demokratis. 
Agar prioritas-prioritas pemerintah dilaksanakan oleh sekolah dan semua aktivitas sekolah ditujukan untuk memberikan pelayanan kepada peserta didik sehingga dapat belajar dengan baik, pemerintah perlu merumuskan seperangkat pedoman umum tentang pelaksanaan MBS. Pedoman-pedoman tersebut terutama ditujukan untuk menjamin bahwa hasil pendidikan (student outcomes) terevaluasi dengan baik, kebijakan-kebijakan pemerintah dilaksanakan secara efektif, sekolah dioperasikan dalam kerangka yang disetujui oleh pemerintah, dan anggaran dibelanjakan sesuai dengan tujuan.

c. Peranan orang tua dan masyarakat

MBS menunut dukungan tenaga kerja yang terampil dan berkualitas untuk membangkitkan motivasi kerja yang lebih produktif dan memberdayakan otoritas daerah setempat, serta mengefesiensikan sistem dan menghilangkan birokrasi yang tumpang tindih. Untuk kepentingan tersebut, diperlukan partisipasi masyarakat.

Partisipasi masyarakat merupakan bagian penting dalam manajemen berbasis sekolah, khususnya dalam pembuatan keputusan. Dengan demikian, masyarakat dapat lebih memahami, dan dapat mengawasi serta membantu sekolah dalam pengelolaan dan kegiatan belajar mengajar. Besaranya partisipasi masyarakat dalam pengelolaan sekolah memungkinkan dapat menimbulkan rancunya kepentingan antar sekolah, orang tua, dan masyarakat. Oleh karenanya, dalam hal ini pemerintah perlu merumuskan bentuk partisipasi (pembagian tugas) setiap unsur secara jelas dan tegas.

d. Peranan profesional dan manajerial

Manajemen berbasis sekolah menuntut perubahan-perubahan tingkah laku kepala sekolah, guru, dan tenaga administrasi dalam mengoperasikan sekolah. Pelaksanaan MBS berpotensi meningkatkan gesekan peranan yang bersifat profesional dan manajerial. Untuk memenuhi persyaratan pelaksanaan MBS, kepala sekolah guru dan tenaga administrasi harus memiliki kedua sifat tersebut yaitu, profesional dan manajerial. 
e. Pengembangan profesi

Dalam MBS pemerintah harus menjamin bahwa semua unsur penting tenaga kependidikan (sumber daya manusia) menerima pengembangan profesi yang diperlukan untuk mengelola sekolah secara efektif. Oleh karena itu perlu adanya pusat pengembangan profesi yang berfungsi sebagai penyedia jasa pelatihan bagi tenaga kependidikan (Mulyasa, 2014: 27-29).

\section{Manajemen Berbasis Sekolah sebagai Proses Pemberdayaan}

Dalam dunia pendidikan, pemberdyaan merupakan cara yang sangat praktis dan produktif untuk mendapatkan hasil yang terbaik. Proses untuk mendapat yang terbaik dan produktif tersebut adalah dengan membagi tanggung jawab secara proporsional kepada para guru. Satu prinsip terpenting dalam pemberdayaan ini adalah melibatkan guru dalam proses pengambilan keputusan dan tanggung jawab.

Dalam MBS sendiri, pemberdayaan dimaksudkan untuk memperbaiki kinerja sekolah agar dapat mencapai tujuan secara optimal, efektif, dan efesien. Pada sisi lain, untuk memberdayakan sekolah harus pula ditempuh upaya-upaya memberdayakan peserta didik dan masyarakat setempat. MBS sebagai proses pemberdayaan merupakan cara untuk membangkitkan kemauan dan potensi peserta didik agar memiliki kemampuan mengontrol diri dan lingkungannya untuk dimanfaatkan bagi kepentingan peningkatan kesejahteraan.

Sedikitnya terdapat delapan langkah pemberdayaaan dalam kaitannya dengan MBS. Delapan langkah tersebut tergambar dalam flow chart sebagai berikut:

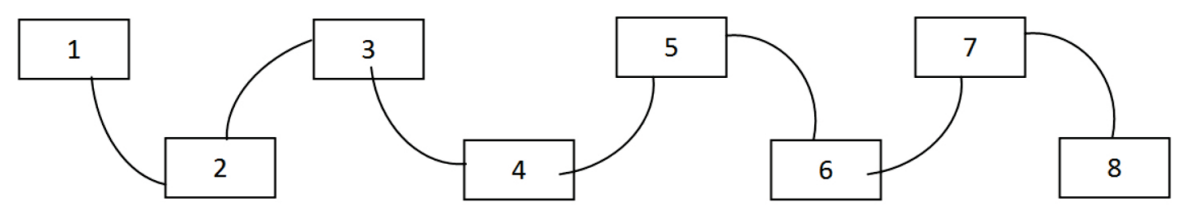

1. Menyusun kelompok guru sebagai penerima awal atas rencana program pemberdayaan

2. Mengidentifikasi dan membangun kelompok peserta didik di sekolah 
3. Memilih dan melatih guru dan tokoh masyarakat yang terlibat secara langsung dalam implementasi manajemen berbasis sekolah

4. Membentuk dewan sekolah yang terdiri dari unsur sekolah, unsur masyarakat di bawah pengawasan pemerintah daerah

5. Menyelenggarakan pertemuan-pertemuan para anggota dewan sekolah

6. Mendukung aktivitas kelompok yang tengah berjalan

7. Mengembangkan hubungan yang harmonis antara sekolah dan masyarakat

8. Menyelenggarakan lokakarya untuk evaluasi

\section{Pendidikan Madrasah}

Kata Madrasah berasal dari bahasa Arab dari akar kata "DarasaYadrusu-Darsan-Madrasatan" yang berarti belajar. Dalam ilmu tata bahasa Arab kata madrasab merupakan dharaf makan yang berarti keterangan tempat, dalam hal ini madrasah berarti tempat belajar. Jika diterjemahkan ke dalam bahasa Indonesia kata "madrasab" memiliki arti "sekolah" meskipun pada mulanya kata "sekolah" bukan berasal dari bahasa Indonesia, melainkan dari bahasa asing yaitu school dan scola. Secara teknis formal dalam proses belajar mengajar antara madrasah dan sekolah tidak memiliki perbedaan, akan tetapi di Indonesia madrasah tidak dengan serta merta dipahami sebagai sekolah, melainkan diberi konotasi yang lebih spesifik lagi yakni "sekolah agama" tempat dimana anak-anak didik memperoleh pembelajaran hal ihwal atau seluk beluk agama dan keagamaan Islam (Hidayat dan Machali, 2012: 127).

Madrasah saat ini sudah menjadi bagian dari budaya Indonesia sebagai lembaga pendidikan Islam. Munculnya madrasah sebagai lembaga pendidikan di Indonesia memberikan banyak coretan sejarah mulai dari zaman kolonial belanda hingga saat ini. Berikut penulis paparkan secara singkat perkembangan sejarah Madrasah di Indoesia.

Pada era kolonialis Belanda, perkembangan madrasah dimulai dari semangat reformasi yang dilakukan masyarakat Muslim. Faktor penting yang melatarbelakangi kemunculan madrasah adalah karena adanya pandangan yang mengatakan bahwa sistem pendidikan Islam tradisional dirasakan kurang bisa memenuhi kebutuhan pragmatis masyarakat. Dan adanya kekhawatiran atas kecepatan perkembangan persekolahan 
Belanda yang akan menimbulkan pemikiran sekuler di masyarakat. Untuk mengimbangi perkembangan sekulerisme, para reformis kemudian memasukkan pendidikan Islam dalam persekolahan melalui pembangunan madrasah.

Pada era Orde Lama, pengaturan dua sistem pendidikan ini kemudian diupayakan untuk dihapus. Paling tidak ada tiga usaha yang dilakukan. Pertama, memasukkan pendidikan Islam ke dalam kurikulum pendidikan umum di sekolah negeri maupun swasta melalui pelajaran agama. Kedua, memasukkan ilmu pengetahuan umum ke dalam kurikulum pendidikan di madrasah. Ketiga, mendirikan sekolah Pendidikan Guru Agama (PGA) untuk memproduksi guru agama bagi sekolah umum maupun madrasah.

Awal pemerintahan Orde Baru (1966), Indonesia mengembangkan dua sistem pendidikan, yaitu pendidikan umum dan keagamaan. Dualisme sistem pendidikan ini sebenarnya produk dari masa kolonialis Belanda. Sistem pendidikan ini pula yang melahirkan dua dasar politik utama, yaitu kekuatan Islam dan nasionalisme. Pada perkembangannya, Pemerintah Indonesia berusaha menyatukannya dalam satu ideologi Pancasila.

Awal pemerintahan Orde Baru, pendekatan legal formal yang dijalankannya tidak memberikan dukungan pada madrasah. Tahun 1972 Presiden Soeharto mengeluarkan Keputusan Presiden (Keppres) Nomor 34 Tahun 1972 dan Instruksi Presiden (Inpres) Nomor 15 Tahun 1974 yang mengatur madrasah di bawah pengelolaan Menteri Pendidikan dan Kebudayaan (Mendikbud) yang sebelumnya dikelola Menteri Agama.

Tanggapan yang muncul di kalangan muslim sangat beragam dan cenderung keras. Kebijakan itu dinilai sebagai usaha sekulerisme dan menghilangkan madrasah dari sistem pendidikan di Indonesia. Merespon reaksi tersebut, pemerintah kemudian mengeluarkan keputusan bersama antara Menteri Pendidikan dan Kebudayaan (Mendikbud), Menteri Agama (Menag), dan Menteri Dalam Negeri (Mendagri). Isinya, mengembalikan status pengelolaan madrasah di bawah Menteri Agama, tetapi harus memasukkan kurikulum umum yang sudah ditentukan pemerintah.

Pada masa reformasi, eksistensi madrasah sebagai lembaga pendidikan Islam semakin diakui oleh pemerintah dengan pemberlakuan Undang-Undang Nomor 20 tahun 2003 tentang Sistem Pendidikan Nasional, yang antara lain ditandai dengan pengukuhan sistem 
pendidikan Islam sebagai pranata pendidikan nasional. Lembaga-lembaga pendidikan Islam kini memiliki peluang lebih besar untuk tumbuh dan berkembang serta meningkatkan kontribusinya dalam pembangunan pendidikan nasional (Wahid, 2008). Saat ini Madrasah sudah menjadi bagian integral dari sistem pendidikan nasioanal di bawah pembinaan Departemen Agama. Hal ini beriringan dengan disahkannya UndangUndang Sistem Pendidikan Nasional Nomor 20 tahun 2003 sebagai ganti Undang-Undang Nomor 2 tahun 1989.

Keberadaan posisi madrasah di bawah Departemen Agama menjadikan madrasah harus menjalankan pengelolaan pendidikan dengan sistem sentralisasi. Artinya semua wewenang terpusat pada pemerintah pusat. Hal ini tentunya terdapat kelemahan dan kelebihan. Namun jika berangkat dari beberapa permasalahan madrasah sebagaimana dijelaskan di atas maka sebenarnya madrasah sudah selayaknya membuka pintu untuk menjalankan sistem desentralisasi pendidikan dengan menerapakan Manajemen Berbasis Sekolah sebagai konsep untuk pengelolaan pendidikan di madrasah.

\section{Manajemen Berbasis Sekolah sebagai Peningkatan Mutu Pendidikan Madrasah}

Setiap lembaga pendidikan pastinya memiliki sasaran akhir yang diharapkan. Sasasran akhir tersebut adalah terjadinya peningkatan mutu. Mutu merupakan derajat keunggulan sebuah produk atau pelayanan. Sebuah produk yang bersaing dengan produk lainnya atau suatu pelayanan jasa bersaing dengan pelayanan jasa lainnya memiliki tingkat keunggulan relatif. Produk atau pelayanan jasa yang lebih unggul adalah produk atau pelayanan jasa yang bermutu. Mutu merupakan kesempatan ajang berkompetisi sangat berharga, karena itu munculnya kompetitor merupakan sebuah wahana untuk meningkatkan mutu produk layanan jasa. Dengan demikian, mewujudkan pendidikan dengan mengikuti standar mutu adalah penting, sebagai bagian dari produk layanan jasa.

Standar yang menjadi acuan pendidikan termasuk di dalamnya madrasah, adalah berdasarkan Peraturan Pemerintah RI nomor 19 tentang Standar Nasional Pendidikan. Sebagaimana yang tercantum dalam Bab II tentang lingkup, fungsi dan tujuan. Pada pasal 2 ayat (1) dinyatakan tentang lingkup Standar Nasional Pendidikan meliputi: standar isi, standar proses, standar kompetensi lulusan, standar pendidik 
dan tenaga kependidikan, standar sarana dan prasarana, standar pengelolaan, standar pembiayaan, dan standar penilaian pendidikan. Pada pasal 54 ayat (4) dinyatakan bahwa pengelolaan pendidikan pada tingkat dasar dan menengah dipertanggungjawabkan oleh satuan pendidikan kepada rapat dewan pendidik, dan komite sekolah/madrasah. Dengan mengacu pada standar ini jelaslah bahwa pengelolaan pendidikan pada madrasah merupakan bagian dari standar pengelolaan dengan melibatkan komite madrasah yang terdiri dari unsur stakeholders, orang tua siswa, dan masyarakat (Rahman, 2012: 228).

Dari penguraian tentang peningkatan kualitas pendidikan di atas kalau dicermati, nampak jelas pentingnya peranan madrasah sebagai pelaku dasar utama yang otonom, dan peranan orang tua dan masyarakat dalam mengembangkan pendidikan. Aktifitas dan dinamika pendidikan termasuk di dalamnya soal kualitas pendidikan bukan pertama-tama ditentukan oleh pihak dari luar madrasah, melainkan oleh madrasah yang bersangkutan dalam interkasinya dengan para pelanggan.

Madrasah sebagai unit pelaksana pendidikan formal yang terdepan dengan berbagai keragaman dan kondisi lingkungan yang berbeda satu dengan lainnya, maka madrasah harus dinamis dan kreatif dalam melaksanakan perannya untuk mengupayakan peningkatan kualitas/mutu pendidikan. Hal ini akan dapat dilaksanakan jika madrasah diberikan kepercayaan untuk mengatur dan mengurus dirinya sendiri sesuai dengan kondisi lingkungan dan kebutuhan pelanggan (Atmodiwirio, 2000: 5-6).

Konsep pemikiran tersebut telah mendorong munculnya pendekatan baru, yakni pengelolaan peningkatan mutu pendidikan yang berbasis madrasah sebagai institusi paling depan dalam kegiatan pendidikan. Pendekatan inilah yang dikenal dengan manajemen peningkatan mutu pendidikan berbasis madrasah (madrasab-based quality management/ Madrasah-based quality improvement) (Suryosubroto, 2004: 204-205). Pada hakekatnya Madrasab-Based Management (MBM) akan membawa kemajuan dalam dua area yang saling tergantung, yaitu pertama, kemajuan program pendidikan dan pelayanan kepada siswa-orang tua, siswa-masyarakat. Kedua, kualitas lingkungan kerja untuk semua anggota organisasi (Nurkolis, 2003: 81).

Berdasarkan fungsi dan manfaat Manjemen Berbasis Madrasah tersebut maka bukanlah langkah yang salah jika madrasah melaksanakan 
pengelolaan manajemen mutu berbasis madrasah dalam rangka peningkatan kualitas pendidikan di madrasah. Apalagi jika melihat berbagai macam persoalan yang ada di madrasah, terutama dalam hal diskriminasi dan kurangnya pemerataan pendidikan dalam lembaga pendidikan Islam. Menurut hemat penulis sistem sentralisasi madrasah tidak semestinya menjadikan madrasah untuk tidak menjalankan konsep Manajemen Berbasis Sekolah. Dalam hal ini madrasah tetap dapat menjalankan pengelolaan manajemen berbasis sekolah yang kemudian menjadi manajemen berbasis madrasah. Sistem sentralisasi tetap melekat pada madrasah yang berfungsi sebagai kontrol dan pengawasan.

\section{Simpulan}

Manajemen Berbasis Sekolah atau School-Based Management meruapakan sebuah konsep manajemen di era otonomi daerah untuk meningkatkan mutu pendidikan. MBS muncul dalam dunia pendidikan setelah terbutnya undang-undang tentang otonomi daerah yang berdampak pada pelaksanaan manajemen sekolah. Pada intinya model MBS adalah manajemen yang memberikan otonomi lebih besar kepada sekolah dan mendorong sekolah untuk melakukan pengambilan keputusan secara partisipatif untuk memenuhi tujuan mutu sekolah dalam kerangka pendidikan nasional.

Konsep Manajemen Berbasis Sekolah ini pada hakikatnya dapat diterapkan di madrasah yang kemudian menjadi istilah Manajemen Mutu Berbasis Madrasah (MMBM). Manajemen Peningkatan Mutu Berbasis Madrasah perlu diterapkan untuk dijadikan solusi terhadap berbagai macam persoalan yang dihadapi Madrasah. Sejauh penelusuran penulis rendahnya kualitas Madrasah disebabkan oleh adanya diskriminasi madrasah, penyelenggaraan pendidikan yang birokrasi-sentralistik, ketidak tepatan kebijkan dan keputusan pemerintah terhadap peningkatan mutu madrasah, dan adanya disharmoni antara madrasah, pemerintah, dan masyarakat.

Melihat berbagai persoalan yang dihadapi madrasah, tepat kirannya jika Manajemen Peningkatan Mutu Berbasis Madrasah diterapkan di madrasah sebagai jawaban atas problem yang ada, dengan tetap berada di bawah kendali dan kontrol pemerintah pusat, sehingga tujuan pendidikan madrasah akan tercapai, jika demikian maka madrasah akan menjadi lembaga pendidikan Islam yang bermutu dan berkualitas. 


\section{Daftar Pustaka}

Atmodiwirio, Soebagio. Manajemen Pendidikan Indonesia. Jakarta: Ardadizyajaya, 2000.

Bafadal,Ibrahim Manajemen Peningkatan Mutu Sekolah Dasar. Jakarta:PT Bumi Aksara, 2006.

Hidayat, Ara dan Machali, Imam. Pengelolaan Pendidikan: Konsep, Prinsip, dan Aplikasi dalam Mengelola Sekolab dan Madrasah. Yogyakarta: Kaukaba, 2012.

Kurniadin, Didin dan Machali, Imam. Manajemen Pendidikan: Konsep dan Prinsip Pengelolaan Pendidikan. Yogyakarta: Ar-ruz Media, 2012.

M. Chan, Sam dan Tuti T. Sam. Kebijakan Pendidikan Era Otonomi Daerah. Jakarta: PT Raja Grafindo Persada, 2007.

Mulyasa,E. Manajemen Berbasis Sekolab: Konsep, Strategi, dan Implementasi. Bandung: PT. Remaja Rosdakarya, 2005. Menjadi Kepala Sekolah Profesional. Bandung: PT. Remaja Rosdakarya, 2011.

- Manajemen Berbasis Sekolah: Konsep, Strategi, dan Implimentasi. Bandung: PT. Remaja Rosdakarya, 2014.

Nugroho, Riant. Kebijakan Pendidikan yang Unggul. Yogyakarta: Pustaka Pelajar, 2008.

Nurkolis. Manajemen Berbasis Sekolah: Teori, Model dan Aplikasi. Jakarta: PT Gramedia Widiasarana Indonesia, 2003.

Rahman, K. A. "Peningkatan Mutu Madrasah melalui Penguatan Partisipasi Masyarakat" Jurnal Pendidikan Islam, 1 (2) Desember 2012: 227-246.

Suryosubroto. Manajemen Pendidikan Sekolah. Jakarta: PT Rineka Cipta, 2004.

Syukri Nafis, Ahmadi H. Manajemen Pendidikan Islam. Yogyakarta: LaksBang PRESSindo, 2011.

Tilaar, H.A.R. Manajemen Pendidikan Nasional, Kajian Pendidikan Masa Depan. Bandung: PT. Remaja Rosdakarya, 2004.

Usman, Husaini. Manajemen: Teori Praktik dan Riset Pendidikan. Jakarta: Bumi Aksara, 2013. 